\title{
Iist of
}

\section{SIMPLI II ED PRACII CE RECOM RNDATIONS} Revised to october 15, 1940.

Simplified Practice means reduction of excessive variety of manufactured products, or of methods. Simnlified practice Recommendations are records of stock itens retained after superfluous variety has been eliainated. These recommendations are cieveloped by voluntary cooperation anong menuiecturers, distributors, consunars, axid other interests, wnon the initiative of eny of these grouns, through a regular procedure of the National. Bur eau of standaras established for that purpose. I

With certain excentions ${ }^{2}$ current recmendations are available in printed form for 5 cents per covy, unless otherwise indicated. When ordering give number and title of the publication, as, for examole, "Rl07-31, Glassine Bags."

A discount of 25 percent will be allowed on orders for 100 or more copies.

DOMESTIC ORDERS fOn publications should bo addressed to the Superintendent of Dccuments, Gover ment Printing fifice, Nashington, D.C., and should be accompanied by coupons (obtainable from the surerintendent of Documents, in sets of 20 for $\$ 1.00$ and good until used), or by checls or money order payable to the "Superintendent of Documents," The prices in this list are for publications which are to be delivered to addresses in the United states and its possessions, and to countries extending the franking privilege.

ORDERS FROM OTHER COUNTES ShS should identify the desired putications by number and title, and should be accomanied by renjitances which include onethird of the total cost of the specified piblications, to cover postage. Remittances should be made payable to the "Superintendent of Documents," and mailed with order to that of ficer at the Goverument printing office, washington, D.C., U.S.A.

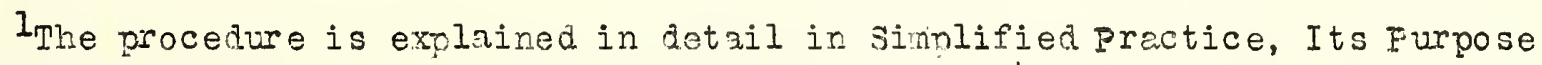
and Application, Letter Circular IC-500, Aorii 15, 1340, Division of Simplified Practice, National Bureau of stanciaras.

$2_{\text {in }}$ mbers indicated by an asterisk (*) are available, at present, only in mimeographed form. They can be obtained, free of chasge, from the Division of Simplified Practice, National Bureau of stanciaru, Washington, D.C. 
$\therefore$ 
Abrasive gratn; sizes of

Abrasive products, coated

Aggregates, coarse (crushed stone, gravei and siag)

Asbestos paper; and asbestos. millboard

Asphalt

Axes, forged.

*RII8-40

$3 * 89-40$

$163-39$

$19-37$
$4-36$

$158-37$

Bags, glassine

Bags, paper, grocers'

Bags, paper, notion and milinery (for department and

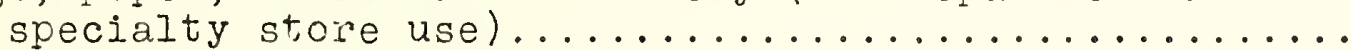

Bank checks, notes, drafts, and similar instruments.

Barrels and drums, steel

Bars, steel; color code for marking

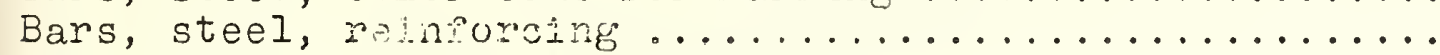

Bars, steel, spirai, reinforcing

Batteries, flashlight; packaging of

Bearings, roller, taper

Beds, hospital

Bedsteads, springs, ard mattresses

Blackboard, compositicn

Blades, hack-saw

Blankets, bed (sizes)

Board, binder's

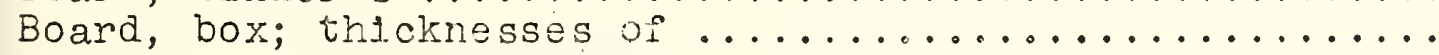

Bobbins, filling cop wirder, hole sizes for; and basic

dimensions for cones for warp and knitting yarns

Bollers, range; and expansion tanks.................

Bollers, steel, heating, horizontal firebox

Bolts, carriage, machine, anc lag; packaging of ........ Bolts, machine, carriage, and lag (steel) (stock produc-

tion sizes).

Bolts, plow

Books, composition

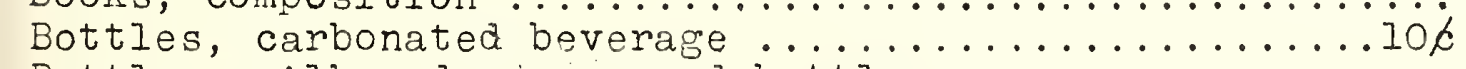

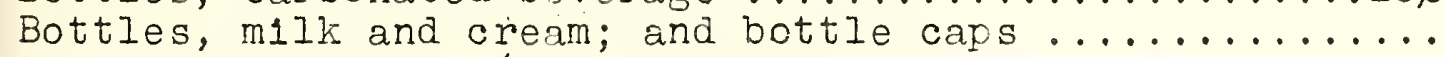

Boxes, corrugated, (for department and specialty store

use).

Boxes, corrugated and solid fiber, for canned fruits and

vegetables

$107-31$
42

*129-31

50

$20-28$

$166-37$

25-30

$53-32$

$104-30$

$67-36$

24-37

$2-32$

$75-29$

90-36

$11-36$

$81-28$

$44-36$

$152-34$

$8-29$

$157-37$

60-30

$169-37$

*23

$84-28$

$123-30$

10

$* 128-31$

$146-38$

Boxes, folding, (for department and specialty store use). Boxes, folding, stock; (for) garments and dry cleaning...

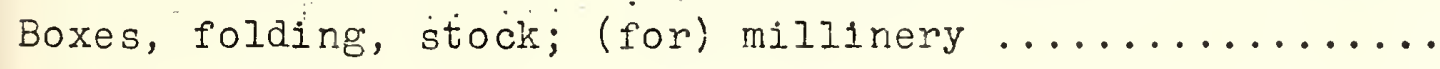

$\because 127-31$

$172-38$

$173-38$ 


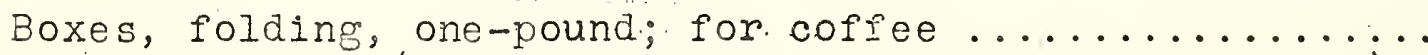
Boxes, set-uo, (for department and specialty store use).. Boxes, wooden, for canned frutts and vegeteoles ........

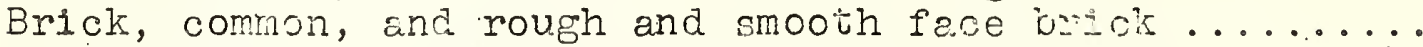
Brick, face, rouk and smooth; and common brick ........ Brick, peiting, vitrilied

Brick, senci-lime

Brushes, calchine; block sizes for

Brushes, oaroon, graphite, and metal-graphite; and brush

shun's

Brusies, counter, window, radiator

Brushes, paint and varnish

R $64-30$

* $126-31$

$171-38$

7

7

$1-40$

$38-37$

$121-31$

$56-35$

$167-37$

$43-28$

Cans, frutt ard vegeteble (names and dimensions)....... Cans, tinned-steei, ¿co cream

Caps, bottie, mise cna cream; and mijk and cream botties.

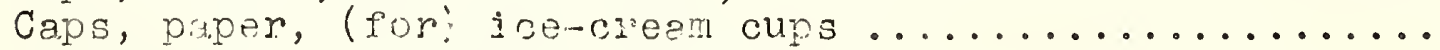
Cartions, ice cceain; and ize cream brick molds ..........

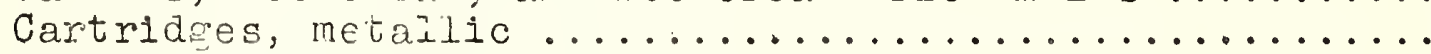
Cases, flashlight, metal and fiber

Chain, weläe $.10 \not$

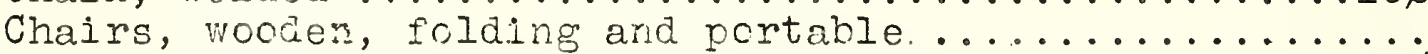

Chasers for seli-opering and ajustabie die heads .... io Checks, bank; and notes, drafis, and similar instruments. Checks, guest, restauraint

Chinaware, cafeteria aid restaurant

Chinaware, dining car

Chinaware, hospital

Chineware, rotel

Cloth, screen, wire insect

Coal, htgh rolatile, sires and terminojogy (Miscelianeous

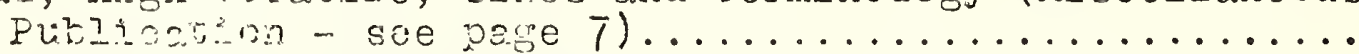
Color cude tis marring steel bars

Color for scinol furntive

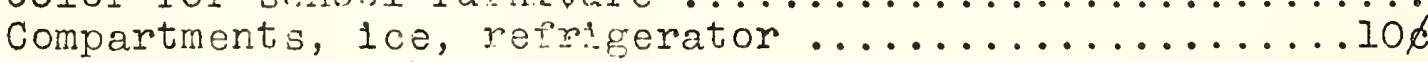

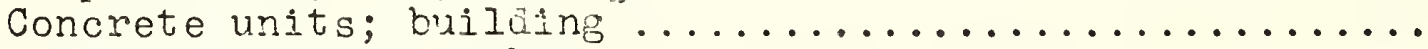
Cones, paper, and tubes tor textile winding

Cones, warp and knitting yarn, bastc dimensions for; and hole sizes for bobbins for filling cop winders .......

*1

$155-40$ $154-36$ 10

$132-36$

$120-40$

$62-39$

$68-33$

$100-29$

$80-28$

$51-29$

50

$113-30$

$166-37$

$111-30$

$109-29$

$32-38$

$143-39$

$152-34$

$175-40$

$* 155-40$

$164-36$

$156-37$

$148-33$ 
Containers, glass; for mayonnaise and kindred products... RI3I-35 Containers, glass; for preserves, jellies, and apple butter Containers for paints, varnishes, and related products... Containers, spice (tin and fiber)

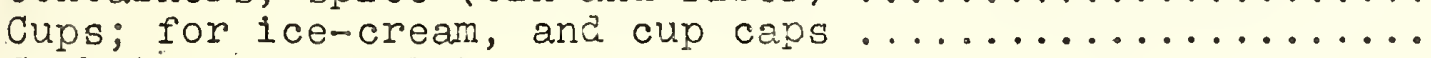

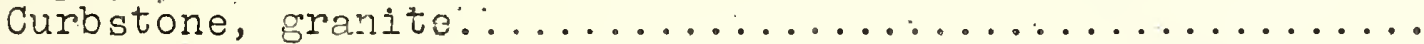
Cutters, miling

Doors, hollow metal single acting swing; frames and trim. Doors, kalamein, single acting swing; frames and trim ...

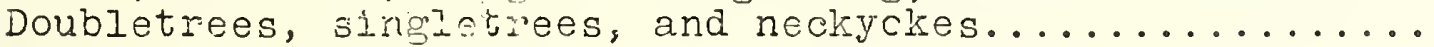

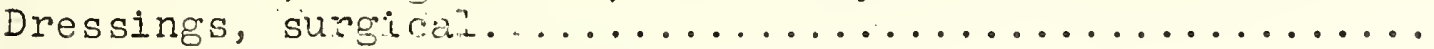

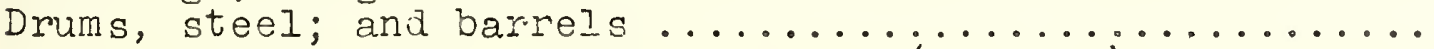
Dry-cleaning boxes, folding, stock; (and for) gaments.. Duck, cotton

91-32

$144-37$

$170-38$

$132-36$

$102-33$

$36-34$

$82-28$

$83-28$

$134-32$

$133-38$ $20-28$ $172-38$ $27-36$

Eaves trough, condector pipe, and futings, and ridge rolls Extractors, comersal Iaundry [..................

Fencing, woven-wire; alld woven-wire fence paokages ..... Files and rasps

F1lm, photographo, for miriature copies of records.... Fittings, eaves tiough, conductor pipe, and ridge rolls.. Fittings, wrought iron and wrought steel, and pipe and valves

Fixtures, plumbing, rospital

Fixtures, plumbing, staple vitreous china

(Included in Commercial Standara CS2O-36)

Flashlight cases, metal. and fiber

Flatware, silver, stering

Forms, bank (chechs, notes, drafts, and similar instru-

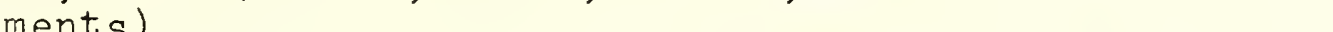

Forms, comercial (invoice, purchase order, and

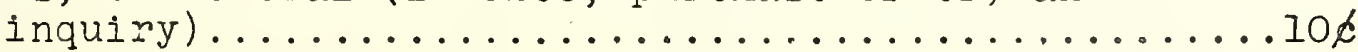

Forms for concrete joist construction floors

Forms, warehouse ........................ Frames; and trim, for hollow metal single acting swing

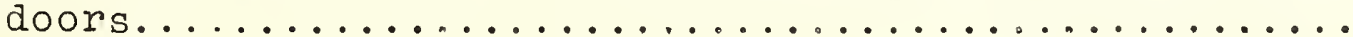

Frames; and trim, ka iamein single acting swing doors ... Fungicides and insecticiaes; agricultural (package sizes) Furniture, school; color for

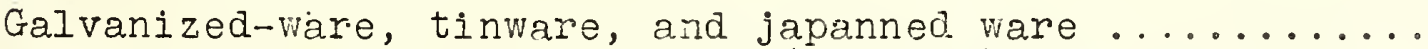
Garment-boxes, folding, stock; (and for) dry-cleaning.... Gauze, surgical
$29-39$

$139-32$

$9-28$
$6-40$

$165-36$

$29-39$

$57-32$

$* 106-30$

52
$68-33$
54

50

$37-38$
$+87-32$
34

$82-28$

$83 \rightarrow 28$

$* 41-40$

$111-30$

55

$172-38$ $86-37$ 
Hammers, forged

$159-37$

Hariles, asi.........

Handles, hickrory

Hardware, bulicers (nonteinplate)

(In=Iuded in Commercial Standard CS22-40) .........

Hatchets, formed

Heads, aje, belf-opening and adjustabie; chasens or Hypodermie neelies; dental

Ice, cake sizes

Insectiaides and fungicides; agricultural (package sizes)

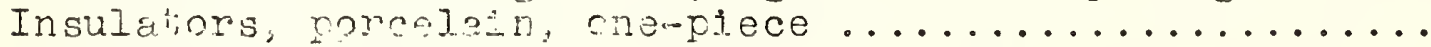

Investmont, dertal; and plaster and antiricial stone;

paringing rot

Invoice paperwontris; ana purchase crass and inquiry

torms .............................

Inquiry paper-forns; and invoice ard purchase order

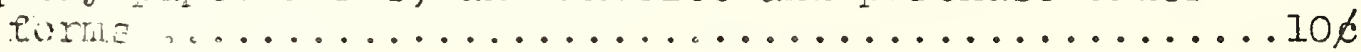

Ironerse, fetwork, commercial laukary $\ldots \ldots \ldots \ldots \ldots \ldots$

$96-28$

*4. $1-40$

$* 73$

$1.17-30$

$37-38$

$37-38$

140.032

Jacks, screvt, bell-bottom

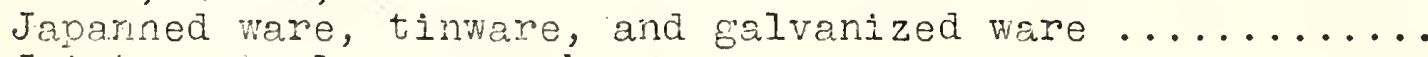

Jols'ús, steel, open-web

$97-30$

55

$94-30$

Knives, pocket

Laces, shoe, braided

$99-30$

Lath, metal (expanded and sheet).

Lights; sikewalk, floor, and roof $\ldots \ldots \ldots \ldots \ldots \ldots \ldots$

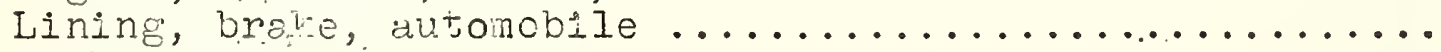

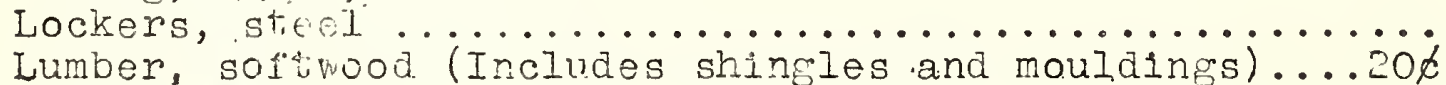
Lumber, ratery-cut; Iumber suock for wire-bound boxes....

49
$* 56$

$35-28$ $16-39$ 59

$2-32$

$19-37$

$173-38$

$137-32$ $120-40$

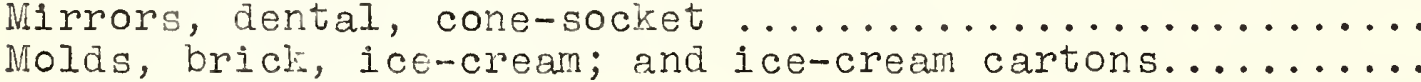

Nails, cut, small; and cut tacks ...............

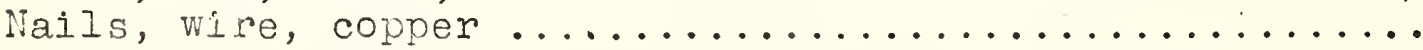

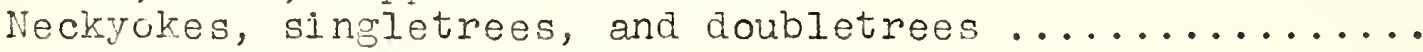
Needles, hypodermic, dental
$47-28$ $150-34$ $134-32$ $108-34$

$$
-4-
$$


Packages,

Packaging

Packaging

Packaging

Packag'ing

Packaging

Packaging

Packaging

Packaging

Packaging dental.

Packaging salt

of bolts

Tarriage, mochine, and las

of encing, woven wire

of flashilght

of

of partis;

of parts;

air brake

engine, automotive (bus)

of parts

motor and

of overhead-material

Inveatoints

and woven-wire fencing

Paints, varnishes, and related proaucts (shales and containers)

Paper, asbestos; end asbestos miliboard

Paper; basic jot Elas for

Paper,

Paper, photograpitio

Paper, tíssue; woxed

Partitions, metal; for toilets and showers

Pipe, conductor; and eaves troigh, and fittings and ridge rolls

Pipe, wrought-iron and wougre-steel; and valves and

\section{fittings}

Plaster, adinesive

Plaster, denial; investment, and astificial stone, packaging of

Platforms, skid

Purchase order paper-forms; and invoice and inquiry forms

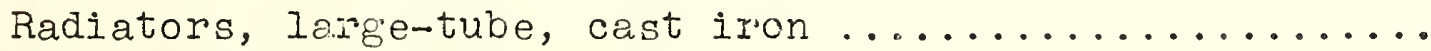
Rasps, and files Refractories, cupola. $10 \not$

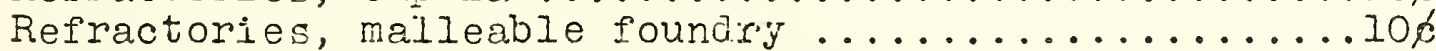
Refrigerators, ice compartment sizes ................. Ridge rolls, eaves trough, conducior plpe, and fittings... Roofing, iron and steol

Rubber, dental (base end veneering)

Scoops, shovels, and spades

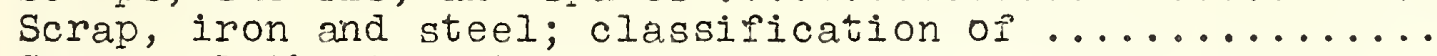
Screen cloth, insect, wire

Screens, production, (for) mineral aggregates; wire diameters for.

Shells, loaded paper shot

Shovels, spades, and scoop

R70

$60-30$

$9-28$

$104-30$

*41-iro

162-35

$161-35$

$145-33$

$65-31$

$117-30$

69

$14.4-37$

19-37

$* 22-33$

$98-36$

$45-39$

$125-31$

*101- 40

29-39

$57-32$
$85-37$

$117-30$

$95-30$

$37-38$

$174-40$

$6-40$

$154-38$

$79-28$

109-29

$29-39$

$78-28$

$138-32$

$* 48$

$58-36$

$122-31$

$147-33$

$31-39$

$* 48$ 
Sieve (screen) tizes of canned peas

RI $49-33$

Singletrees, doubletrees, and neckyokes

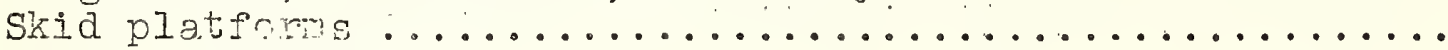

S]ate, blacisoard

Slate,

roofing

Slate, sthicutral

Spades, shovels, and scoop

Spioe contajriers (tin and iber)

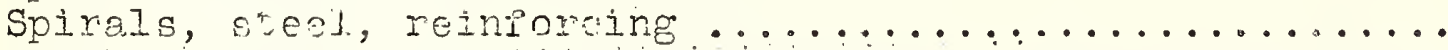
Spools, metal: foc anriseling, handing, and shipping wire. Springs, bedsieads, and mattresses

Steel joists, open-web

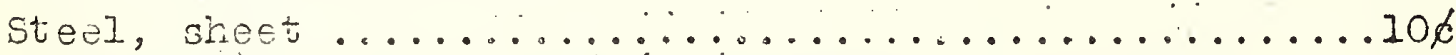

Stcne, a tifider, cetral; piester and investment,

pacisang of.

Sweepe, i־cor

$95-30$

$* 15-35$

$47-28$

$13-28$

$\because 48$

$170-38$

$53-32$

63

$2-32$

$94-30$

$28-29$

$117-30$
$88-37$

$47 \cdots 28$

$93-39$
$8-29$

* 25

$114-30$

$30-37$

$* 12$

$61-30$

55.

$103-33$
$17-35$

$119-31$

*2I

$82-28$

$83-28$

29-39

$14-3-39$

153-34

$135-32$

$141-32$

7].-28

$124-31$

$136-32$

Twine, flax ard hemp 
Title

S.P.R. No.

Twine, soft-fiber (jute).

RIIO-29

Twine, hard-fiber; and lath yarn (piy and yarn goods)....

$92-38$

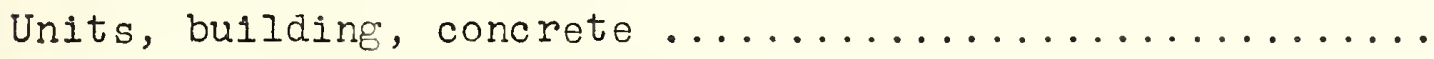

$32-38$

Valves, wrought-iron and wrought-steel; and pipe and

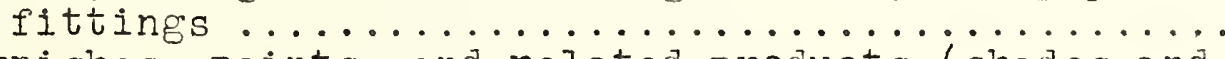

Varnishes, paints, and reiated products (shades and containers).

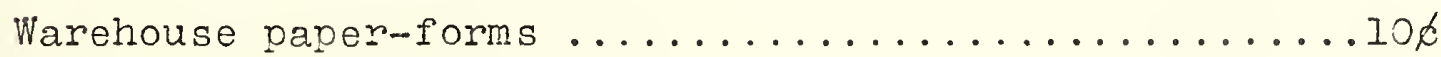

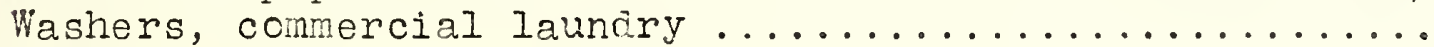

Wheelbarrows

Wireels, brush, dental

$\dot{10 \dot{x}}$

Wheels, buffing, full disk

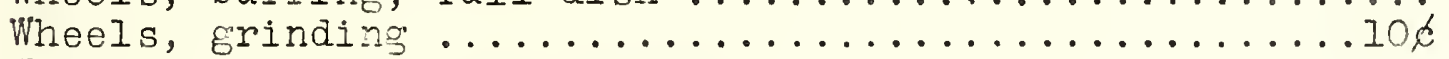

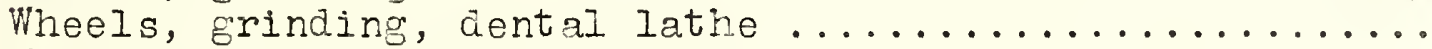

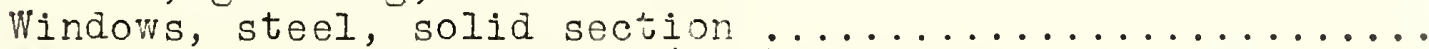

Wire, screen, production, (for) mineral aggregates;

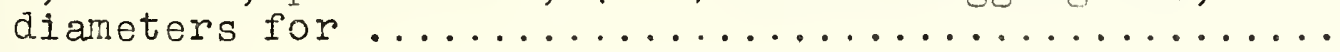

Yarn, lath; and twine, hard-piber (ply and yain goods)... 92-38

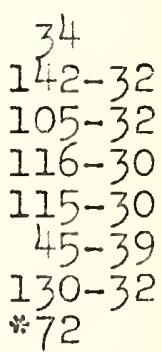

$147-33$

\section{MISCELLANEOUS PUBLICATIONS}

Simplification of sizes and terminology of high volatile bituminous coal
WISCELI_ANEOUS FUBLICATION NO. 113 
‥ 